\author{
폴리에틸렌 표면에 글리시딜메타크릴레이트의 \\ 플라즈마 유도 그래프트 공중합 \\ 김지은 · 류욱연 · 최호석` · 김재하* - 박한오* \\ 충남대학교 공과대학 화학공학과 \\ *(주)바이오니아 \\ (2011년 6월 14일 접수, 2011년 8월 2일 수정, 2011년 8월 30일 채택)
}

\title{
Plasma-induced Graft Copolymerization of Glycidyl Methacrylate on the Surface of Polyethylene
}

\author{
Jieun Kim, Xuyan Liu, Ho-Suk Choi ${ }^{\dagger}$, Jae Ha Kim*, and Han Oh Park* \\ Department of Chemical Engineering, Chungnam National University, 220 Gung-dong, Yuseong-gu, Daejeon 305-704, Korea \\ *Bioneer Co. 49-3, Munpyeong-dong, Daedeok-gu, Daejeon 306-220, Korea \\ (Received June 14, 2011; Revised August 2, 2011; Accepted August 30, 2011)
}

\begin{abstract}
초록: 대기압 플라즈마 처리 및 글리시딜 메타크릴레이트(glycidyl methacrylate, GMA) 그래프트 공중합을 통해 폴리에 틸렌(polyethylene, PE)의 표면을 개질하였다. 우선 RF-power, 플라즈마 처리시간, Ar의 유량, 처리 시편의 이동속도를 변화시켜 $\mathrm{PE}$ 의 표면을 플라즈마 처리하고, 처리된 각 시편들의 접촉각 측정과 표면자유에너지 계산 을 통하여 최적의 플라즈마 표면처리 조건을 구하였다. 그 결과 최적 표면처리 조건은 RF-power $200 \mathrm{~W}$, 플라즈마 처리시간 $600 \mathrm{sec}, \mathrm{Ar}$ 유량 $5 \mathrm{LPM}$, 처리 시편의 이동속도 $20 \mathrm{~mm} / \mathrm{sec}$ 이었다. 이 조건하에서 처리된 $\mathrm{PE}$ 표면에 $\mathrm{GMA}$ 를 최대한 많이 도입하기 위하여 GMA 농도와 반응온도, 반응시간을 변수로 그래프트 공중합을 수행하였 다. 반응전후 시편의 질량차이 분석을 통하여 각 시편들의 그래프트도(grafting degree, GD)를 측정하고, 가장 높 은 $\mathrm{GD}$ 를 얻을 수 있는 그래프트 공중합 반응조건을 결정하였다. 그 결과 $\mathrm{GMA}$ 최대 도입 조건은 $\mathrm{GMA}$ 농도 $20 \mathrm{vol} \%$, 반응온도 $80{ }^{\circ} \mathrm{C}$, 반응시간 $4 \mathrm{hr}$ 이었다.
\end{abstract}

\begin{abstract}
The surface of polyethylene (PE) was modified through Ar atmospheric pressure plasma treatment and subsequent grafting of glycidyl methacrylate (GMA). Optimum plasma treatment conditions were determined through analyzing the surface free energies calculated from the contact angles between PE samples and three probe liquids, which were RF-power of $200 \mathrm{~W}$, plasma treatment time of $600 \mathrm{sec}$, Ar flow rate of $5 \mathrm{LPM}$, and sample-holder moving speed of $20 \mathrm{~mm} / \mathrm{sec}$. To introduce the maximum amount of GMA on PE surface treated under the conditions, graft copolymerization conditions such as GMA concentration, temperature, and time were carefully controlled. Grafting degree (GD) was obtained through weight difference analysis of PE film before and after graft copolymerization. A maximum GD was achieved at the GMA concentration of $20 \mathrm{vol} \%$, the temperature of $80{ }^{\circ} \mathrm{C}$, and the treatment time of $4 \mathrm{hr}$.
\end{abstract}

Keywords: atmospheric pressure plasma treatment, plasma-induced grafting, polyethylene, glycidyl methacrylate, graft copolymerization.

\begin{abstract}
서 론
폴리에틸렌(polyethylene, $\mathrm{PE}$ )은 각종 용기, 포장용 필름, 섬유, 파이프, 패킹 등에 사용되는 가장 대중적인 고분자 중 하나이다. $\mathrm{PE}$ 는 유연성, 화학안정성, 내수성, 절연성과 같은 바람직한 물성을 갖고 있으나, 화학적으로 안정하고, 표면
\end{abstract}

\footnotetext{
"To whom correspondence should be addressed.

E-mail: hchoi@cnu.ac.kr
}

자유에너지가 낮아 접착력이나 인쇄적응성, 젖음성 등에 한 계가 있어 그 응용이 제약되기도 한다. 이를 개선하기 위해 우수한 벌크성질은 그대로 유지하면서 표면의 성질만을 변형시키는 표면개질과 관련된 연구가 활발히 진행되고 있다. ${ }^{1-6}$ 현재 고분자의 표면을 개질하는 기술들 중에 감마 선( $\gamma$-ray), 전자빔(electron beam), 플라즈마(plasma), 자외 선(ultra violet) 등 여러 가지 표면 처리방법이 쓰이는데, 그 중에 플라즈마를 이용한 표면 처리가 유용하게 쓰이고 있다..$^{7-9}$ 플라즈마는 고분자 표면뿐만 아니라 내부에도 라 디칼 생성이 용이하여 고분자에 여러 가지 관능기를 도입할 
수 있는 장점이 있다. 대기압 저온 플라즈마는 상압에서 대 면적으로 대량처리가 용이하고 연속공정이 가능하며, 피 처리물의 열 변형을 일으키지 않는다는 장점이 있다. ${ }^{10}$ 또한 대기 중에 노출되어 있기 때문에 불활성기체를 사용하더라 도 피처리 물질의 표면에 도입된 라디칼이 대기 중의 산소 또는 수증기와 반응하여 산소함유 반응성관능기들을 쉽게 형성할 수 있다. 이 중 하이드로퍼옥사이드(hydroperoxide)와 같은 반응성 관능기들은 추가적인 그래프트 공중합반응의 개시제 역할을 할 수 있고, 이러한 방법으로 다양한 기능성 관능기들을 함유한 고분자를 $\mathrm{PE}$ 와 같은 올레핀 고분자의 표 면 위에 쉽게 도입할 수 있다. 이러한 방법을 플라즈마 유도 그래프트 공중합(plasma induced graft copolymerigzation)이 라고 하며, ${ }^{11,12}$ 본 연구에서는 단량체로 글리시딜 메타크릴 레이트(glycidyl metacrylate, GMA)를 사용하여 반응성이 우 수한 에폭시기를 다량 함유한 $\mathrm{PE}$ 표면을 구현하고자 하였 다. GMA는 그래프트 공중합의 전구체로 잘 알려져 있는 단량체이며, GMA 내의 에폭시기(epoxy group)는 접착력을 향상시켜줄 뿐만 아니라, 이온교환과 유해가스의 흡수를 하는 관능기이다. 또한 카르복시(carboxy), 안하이드라이드 (anhydride), 아미노(amino), 하이드록실(hydroxyl)기 들과 반응하여 항체, 단백질, DNA 등의 고정화에 활용되어 진 단용 바이오웰의 제작에 사용될 수도 있다. ${ }^{13}$ Martel는 ${ }^{14}$ 폴리프로필렌에 에폭시기를 이용하여 cyclodextrins을 도 입하였으며, Huang는 ${ }^{15}$ 에폭시기와 아민(amine), 하이드록 실기와의 반응성 연구에 ${ }^{16,17}$ 기초하여 새로운 중합방법을 연 구하였다.

본 연구에서는 대기압 저온 플라즈마 표면처리 장비를 사용하여 $\mathrm{PE}$ 의 표면 자유에너지가 최대가 되도록 처리 시 간, RF(Radio Frequency)-power, 주입가스 유량, 피처리제의 이동속도를 최적화하였다. 또한 이처럼 표면 자유에너지가 최대화된 $\mathrm{PE}$ 표면 위에 $\mathrm{GMA}$ 를 최대로 도입하기 위하여 단량체의 농도, 반응 온도, 반응시간을 최적화하였다.

\section{실 험}

실험 장치. $\mathrm{PE}$ 의 표면 처리를 위해 대기압 플라즈마 장치 (ATMOS, Plasmart Co.)를 사용하였다. 이는 $13.56 \mathrm{MHz}$ 의 주 파수를 갖는 $0 \sim 300 \mathrm{~W}$ 의 비교적 낮은 전력을 이용해 플라즈 마를 발생시키는 저온 평판형 장치이다. 시편홀더와 glow discharge 사이의 높이 조절이 가능하고 처리시간, 시료 홀더 이동 거리 및 속도조절이 용이하다. 이는 플라즈마 발생 시 열에 의한 기판 손상을 방지하는 역할을 한다. 대기압 플라 즈마 처리된 시료의 접촉각 측정을 위해 접촉각 측정기 (DSA 100, KRUSS Inc., Germany)를 사용하였다. 마이크로 실린지를 사용하여 3 종의 지시액적(증류수, 에틸렌 글리콜, 디아이오도메탄)을 떨어뜨려 정적인 접촉각 측정을 수행하 였다. 플라즈마 처리를 한 $\mathrm{PE}$ 시편에 $\mathrm{GMA}$ 를 그래프트 중합시키기 위하여 실리콘 오일배스와 삼구 조인트 플라스 크, 냉각콘덴서로 구성된 장치를 사용하고, 그래프트 공중
합 후 시편을 건조시키기 위해 진공 오븐을 사용하였다.

실험 재료. 대기압 플라즈마 처리를 위한 시료로 두께 0.80 0.90 mm인 고밀도 PE plate를 사용하였다. 접촉각 측정을 위한 지시 액체로는 2차 증류수와 디아이오도메탄 (99+\%, Acros Organics Co.), 에틸렌글리콜(99+\%, Acros Organics Co.)의 3종을 사용하였다. 플라즈마 처리 후 그 래프트 공중합에 $\mathrm{GMA}(97.0 \%$, Samchun Chemical Co.)를 사용하였으며, 동일 회사 제품인 에탄올( $95.0 \%)$ 을 용매로 사용하였다.

대기압 플라즈마 처리. $\mathrm{PE}$ 시편의 플라즈마 처리를 위해 서는 $\mathrm{Ar}$ 가스를 사용하였다. 플라즈마 처리 시간(sec), RFpower(W), 플라즈마 처리 시편 홀더의 이동속도 $(\mathrm{mm} / \mathrm{sec})$, $\mathrm{Ar}$ 가스 유량 $(\mathrm{L} / \mathrm{min}, \mathrm{LPM})$ 을 변수로 플라즈마 표면처리 효 과를 최적화하였다. Table 1에 플라즈마 처리 조건들의 범 위를 나타내었다. 플라즈마 처리 후 라디칼이 도입된 $\mathrm{PE}$ 시편들은 대기 중에 5 분 동안 노출시킴으로써 하이드로퍼 옥사이드들이 최대로 형성되도록 하였다. ${ }^{7}$

GMA 그래프트 공중합. 앞서 최적화된 플라즈마 처리조 건 하에서 처리된 $\mathrm{PE}$ 기판을 질소 분위기에서 반응 온도는 $60 \sim 80^{\circ} \mathrm{C}, \mathrm{GMA}$ 의 농도는 $5 \sim 30 \mathrm{vol} \%$ 로 변화시키면서, $1 \sim 7 \mathrm{hr}$ 동안 처리하여 $\mathrm{PE}$ 기판에 $\mathrm{GMA}$ 의 그래프트 공중합을 실시 하였다. 그래프트 반응 후 처리된 $\mathrm{PE}$ 시편들은 초음파 세척 하여 표면에 중합되지 않고 남아있는 $\mathrm{GMA}$ 를 제거하였다. 진공에서 $40^{\circ} \mathrm{C}, 24 \mathrm{hr}$ 동안 건조시키고, 무게측정을 통하여 그래프트도(grafting degree, GD)를 측정하였다. Figure 1은 본 연구의 전반적인 메커니즘을 나타내고 있다.

Table 1. Experimental Conditions of Plasma Treatment

\begin{tabular}{ccc}
\hline Gas & Dependent & Value \\
\hline \multirow{4}{*}{ Ar } & Power(W) & $0,50,100,150,200$ \\
& Time(sec) & $0,30,60,120,180$, \\
& Ar flow rate(LPM) & $300,600,2400$ \\
& Moving speed(mm/s) & $0,3,5,8$ \\
\end{tabular}

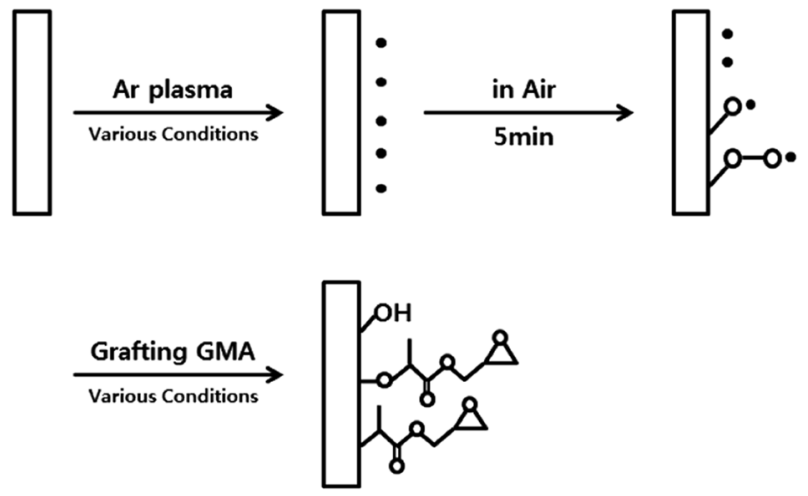

Figure 1. Overall reaction mechanism. 
접촉각 측정과 표면 자유에너지 계산. 대기압 플라즈마 처리 전후 시료의 접촉각을 측정하여 표면 자유에너지를 계산하였다. 시료를 플라즈마 처리한 후 하이드로퍼옥사이 드를 최대로 도입하기 위하여 접촉각 측정하기까지의 대기 중 노출 시간은 5 분으로 고정하였다. 마이크로 실린지로 액 적을 시료 위에 떨어뜨린 후 시료 당 6 10번 측정된 접촉 각 측정값을 평균내어 사용하였다. 그 후 이 값들을 이용해 $\mathrm{PE}$ 시편의 표면 자유에너지를 계산하였다.

액체 표면에너지 성분에 따른 해석방법은 측정용액의 개수에 따라 나뉘게 되는데, 그 중에서 3 종의 지시액적과 시편 표면과의 접촉각들을 이용하는 Lewis Acid/Base 모델을 적용하여 표면 자유에너지를 계산하였다. 이는 정확한 표면 에너지를 구할 수 있고, 산-염기 성분들에 대한 정보를 얻을 수 있기 때문에 현재 가장 널리 쓰이는 방법이다. ${ }^{18} \mathrm{Jung}^{19}$ 은 세 가지 지시액적을 사용하여 접촉각으로 $\mathrm{ITO}$ 의 표면 자유에너지를 연구하였다. 본 실험에서는 표면 자유에너 지를 통하여 플라즈마 처리된 $\mathrm{PE}$ 표면에 생성된 그래프 트 공중합 반응의 개시제인 하이드로퍼옥사이드를 최대로 도입하게 하는 플라즈마 조건을 선정하였다.

$\mathrm{GD}$ 산출. 그래프트 공중합 반응 후 $\mathrm{PE}$ 시편의 표면에 형성된 그래프트 고분자를 정량화하기 위해 무게 측정법을 이용하였다. GMA 그래프트 공중합 반응 전후 플라즈마 처리한 $\mathrm{PE}$ 시편들의 무게 차이를 시편의 단위 면적으로 나누어 $\mathrm{GD}$ 를 식 (1) 로 산출하였다.

$$
G D=\frac{W_{\mathrm{g}}-W_{\mathrm{o}}}{S}\left(\mu \mathrm{g} / \mathrm{cm}^{2}\right)
$$

여기에서 $W_{\mathrm{g}}$ 와 $W_{\mathrm{o}}$ 는 각각 그래프트 공중합 반응 후와 전의 $\mathrm{PE}$ 시편들의 질량이며, $S$ 는 $\mathrm{PE}$ 시편의 표면적이다.

표면 분석. 접촉각 측정과 $\mathrm{GD}$ 산출만으로는 그래프트 고분자의 성공적인 도입여부를 직접 확인할 수 없기 때문에 ATR-FTIR(ALPHA-P, Bruker)을 이용하여 그래프트 중합 반응 전후 시편들의 표면분석을 수행하였다. 아울러 플라즈 마 처리 전, 플라즈마 처리 후, 그래프트 중합 반응 후 시 편들의 원소 구성비와 각 원소의 화학결합 상태를 분석하기 위해 XPS(MultiLab 2000, Thermo)를 사용하였다. 또한 $\mathrm{SEM}(\mathrm{JSM}-7000 \mathrm{~F}, \mathrm{JEOL})$ 분석을 통하여 표면 구조 관찰 을 수행하였다.

\section{결과 및 토론}

대기압 플라즈마 처리. RF-Power의 영향: 플라즈마 RF-power 변화에 따른 접촉각 및 표면 자유에너지 변화를 각각 Figure 2와 Table 2에 나타내었다. 다른 처리조건들은 처리시간 $180 \mathrm{sec}, \mathrm{Ar}$ 가스의 유량 $5 \mathrm{LPM}$, 시편의 이동속도 $20 \mathrm{~mm} / \mathrm{sec}$ 로 고정시켰다. 플라즈마 처리 후에 접촉각은 낮아지고 표면 자유에너지는 높아지는 경향을 보였다. 이를

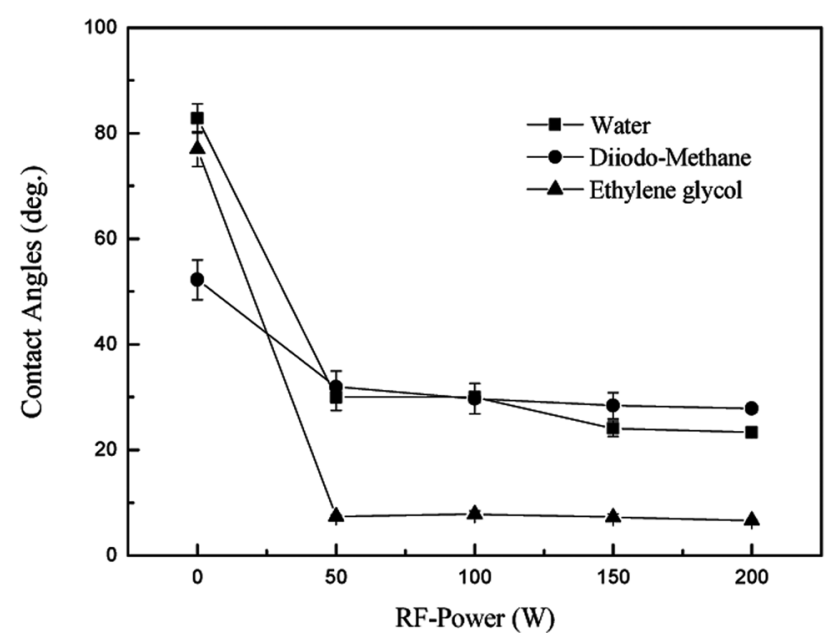

Figure 2. Change of contact angle with respect to plasma treatment power. (300 sec $-5 \mathrm{LPM}-20 \mathrm{~mm} / \mathrm{s})$.

Table 2. Change of Surface Free Energy with Respect to Plasma Treatment Power (300 sec -5 LPM -20 mm/s)

\begin{tabular}{cccccc}
\hline RF-power(W) & 0 & 50 & 100 & 150 & 200 \\
\hline $\begin{array}{c}\text { Surface free } \\
\text { energy }\left(\mathrm{mJ} / \mathrm{m}^{2}\right)\end{array}$ & 45.28 & 80.36 & 81.21 & 83.86 & 84.35 \\
\hline
\end{tabular}

통해 RF-power의 세기가 증가함에 따라 PE 표면이 화학 적으로 활성화되어 소수성에서 친수성으로 변화한다는 것 을 알 수 있었다. 또한 소수성을 지니는 $\mathrm{PE}$ 표면이 플라 즈마 처리를 통하여 하이드로퍼옥사이드나 알코올기와 같 은 극성관능기가 도입되어 그래프트 공중합 반응의 개시 제로 작용한다. 표면 자유에너지가 높은 값을 가질수록 극성관능기의 도입이 용이해진다는 것을 나타내므로 표면 자유에너지가 높은 값을 가지는 조건을 최적의 조건으로 볼 수 있다. 플라즈마 처리 RF-power가 $200 \mathrm{~W}$ 일 경우 표면 자유에너지 값이 가장 높고, 이 값에서 극성기여도가 가장 높았기 때문에 이 조건을 플라즈마 처리 RF-power의 최 적조건으로 정하였다.

처리 시간의 영향: 플라즈마 처리 시간에 따른 접촉각 및 표면 자유에너지 변화를 Figure 3과 Table 3에 나타내 었다. 다른 처리조건들은 RF-power $200 \mathrm{~W}, \mathrm{Ar}$ 가스의 유량 $5 \mathrm{LPM}$, 시편의 이동속도 $20 \mathrm{~mm} / \mathrm{sec}$ 로 고정시켰다. 플라 즈마 처리 후에 접촉각은 낮아지고 자유에너지는 높아지는 경향을 보였다. 그러나 플라즈마 처리 시간이 $600 \mathrm{sec}$ 와 $2400 \mathrm{sec}$ 일 때의 접촉각 값이 크게 줄지 않고 비슷한 것 으로 보아, $600 \mathrm{sec}$ 이상에서는 처리시간의 영향이 별로 없음을 알 수 있었다. 따라서 이 후의 모든 플라즈마 처 리는 $600 \mathrm{sec}$ 로 고정하였다.

$\mathrm{Ar}$ 가스 유량의 영향: $\mathrm{Ar}$ 가스 유량은 발생하는 플라 즈마의 밀도를 조절하는 중요한 변수로, 아르곤 가스 유 량을 3 8 LPM으로 변화시키면서 접촉각과 표면 자유에너 


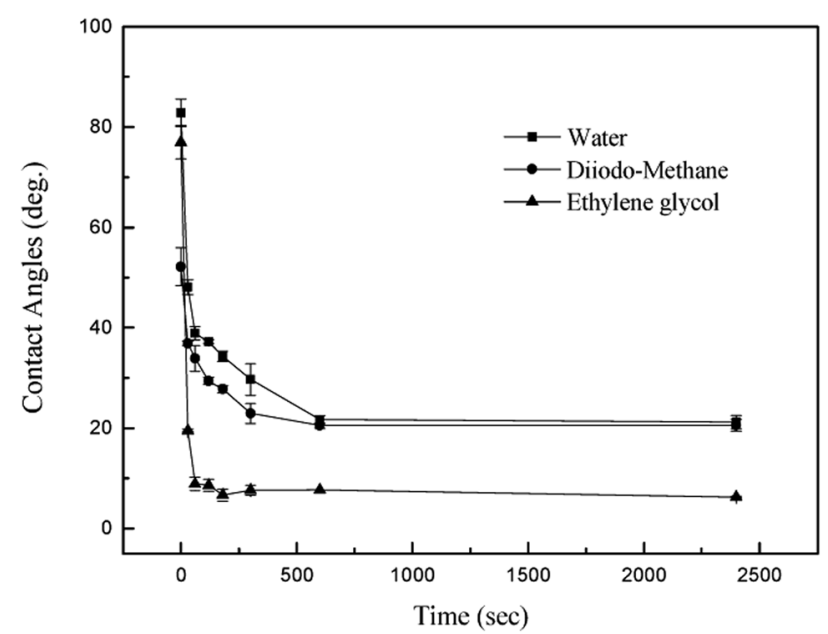

Figure 3. Change of contact angle with respect to plasma treatment time. $(200 \mathrm{~W}-5 \mathrm{LPM}-20 \mathrm{~mm} / \mathrm{s})$.

Table 3. Change of Surface Free Energy with Respect to Plasma Treatment Time (200 W -5 LPM $-20 \mathrm{~mm} / \mathrm{s})$

\begin{tabular}{ccccccccc}
\hline Time $(\mathrm{sec})$ & 0 & 30 & 60 & 120 & 180 & 300 & 600 & 2400 \\
\hline $\begin{array}{c}\text { Surface free } \\
\text { energy }\left(\mathrm{mJ} / \mathrm{m}^{2}\right)\end{array}$ & 45.28 & 70.02 & 75.78 & 78.24 & 76.19 & 83.67 & 87.3 & 87.41 \\
\hline
\end{tabular}

지의 변화를 관찰하였다. 플라즈마 처리에 사용된 $\mathrm{Ar}$ 가스 유량의 영향에 따른 접촉각 및 표면 자유에너지 변화를 Figure 4와 Table 4에 나타내었다. 다른 처리조건들은 RFpower $200 \mathrm{~W}$, 처리시간 $600 \mathrm{sec}$, 시편의 이동속도 $20 \mathrm{~mm} / \mathrm{sec}$ 로 고정시켰다. $\mathrm{Ar}$ 가스의 유량이 높아질수록 접촉각이 낮 아지는 경향을 보이며 표면 자유에너지는 높아지는 경향 을 보인다. 그러나 $3 \mathrm{LPM}$ 이상에서는 접촉각의 변화가 크 지 않으므로 비용적인 측면을 고려하여, 가장 적당한 5 $\mathrm{LPM}$ 으로 고정하였다.

시편 이동속도의 영향: 플라즈마 처리 시 $\mathrm{PE}$ 시편의 이동 속도의 영향에 따른 접촉각 및 표면 자유에너지 변화를 Figure 5와 Table 5에 나타내었다. 다른 처리조건들은 RFpower $200 \mathrm{~W}$, 처리시간 $600 \mathrm{sec}, \mathrm{Ar}$ 가스의 유량 $5 \mathrm{LPM}$ 으로 고정시켰다. 시편의 이동속도에 따라서는 $10 \mathrm{~mm} / \mathrm{sec}$ 이상에서는 접촉각이나 표면에너지의 변화가 크지 않았다. 따라서 높은 표면 자유에너지를 가지면서도 적당한 시편 이동속도인 $20 \mathrm{~mm} / \mathrm{sec}$ 를 최적조건으로 고정하였다.

GMA 그래프트 공중합 후 변화. GMA 농도에 대한 영향: $\mathrm{Ar}$ 플라즈마 처리조건으로는 앞서 최적화된 조건인 RF-power $200 \mathrm{~W}$, 처리시간 $600 \mathrm{sec}, \mathrm{Ar}$ 가스의 유량 $5 \mathrm{LPM}$, 시편의 이동속도 $20 \mathrm{~mm} / \mathrm{sec}$ 로 고정시켰다. Figure 6 은 GMA 농도가 $\mathrm{GD}$ 에 미치는 영향을 조사하기 위하여 GMA의 농 도를 변화시켜 그래프트 공중합한 결과이다. 반응 온도는 $70{ }^{\circ} \mathrm{C}$, 반응 시간은 4시간으로 고정시키고, $\mathrm{GMA}$ 농도를 $5 \sim 30 \mathrm{vol} \%$ 로 변화를 주면서 실험을 진행하였다. GMA의

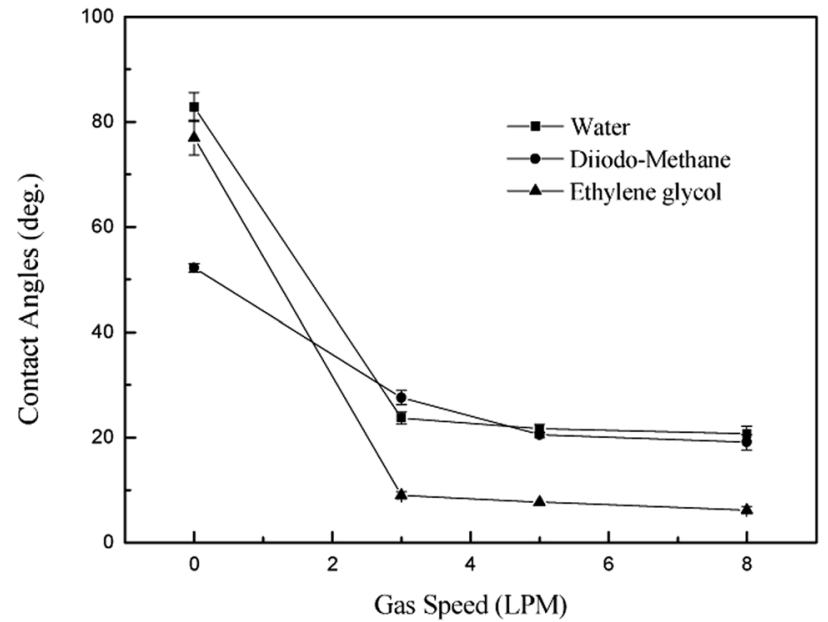

Figure 4. Change of contact angle with respect to Ar gas flow rate. $(200 \mathrm{~W}-600 \mathrm{sec}-20 \mathrm{~mm} / \mathrm{s})$.

Table 4. Change of Surface Free Energy with Respect to Ar Flow Rate $(200 \mathrm{~W}-600 \mathrm{sec}-20 \mathrm{~mm} / \mathrm{s})$

\begin{tabular}{ccccc}
\hline Ar flow rate $(\mathrm{LPM})$ & 0 & 3 & 5 & 8 \\
\hline Surface free energy $\left(\mathrm{mJ} / \mathrm{m}^{2}\right)$ & 45.28 & 84.31 & 87.3 & 87.29 \\
\hline
\end{tabular}

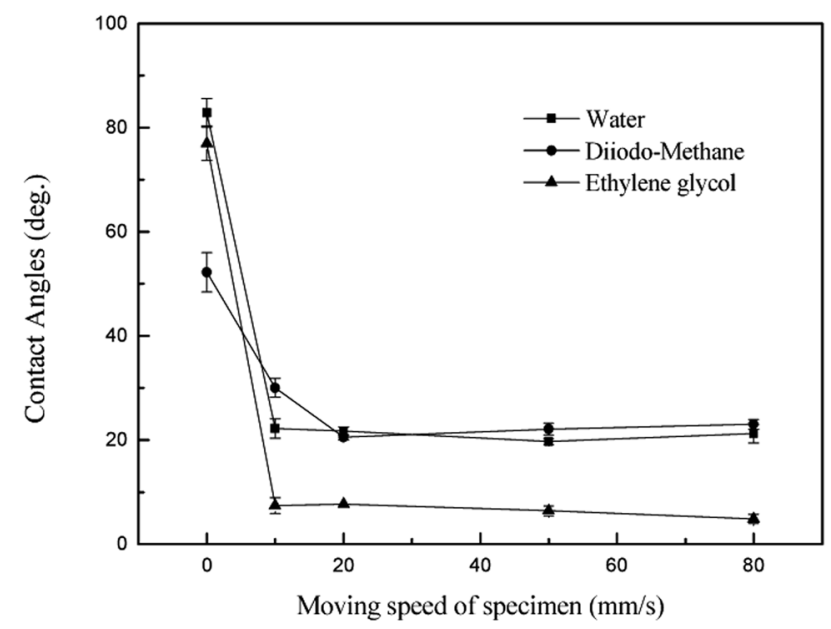

Figure 5. Change of contact angle with respect to moving speed of specimens. (200 W $-600 \mathrm{sec}-5 \mathrm{LPM})$.

Table 5. Change of Surface Free Energy with Respect to Moving Speed of Specimen (200 W $-600 \mathrm{sec}-5$ LPM)

\begin{tabular}{cccccc}
\hline $\begin{array}{c}\text { Moving speed of } \\
\text { specimen }(\mathrm{mm} / \mathrm{s})\end{array}$ & 0 & 10 & 20 & 50 & 80 \\
\hline Surface free energy $\left(\mathrm{mJ} / \mathrm{m}^{2}\right)$ & 45.28 & 83.86 & 87.3 & 87.41 & 86.66
\end{tabular}

농도가 증가함에 따라 $\mathrm{GD}$ 가 증가하여 $20 \mathrm{vol} \%$ 지점에서 최고점을 나타내었으나, $25 \mathrm{vol} \%$ 부터 감소하는 경향을 보 인다. 일반적으로 $\mathrm{GMA}$ 의 농도가 증가할수록 GD가 증가 


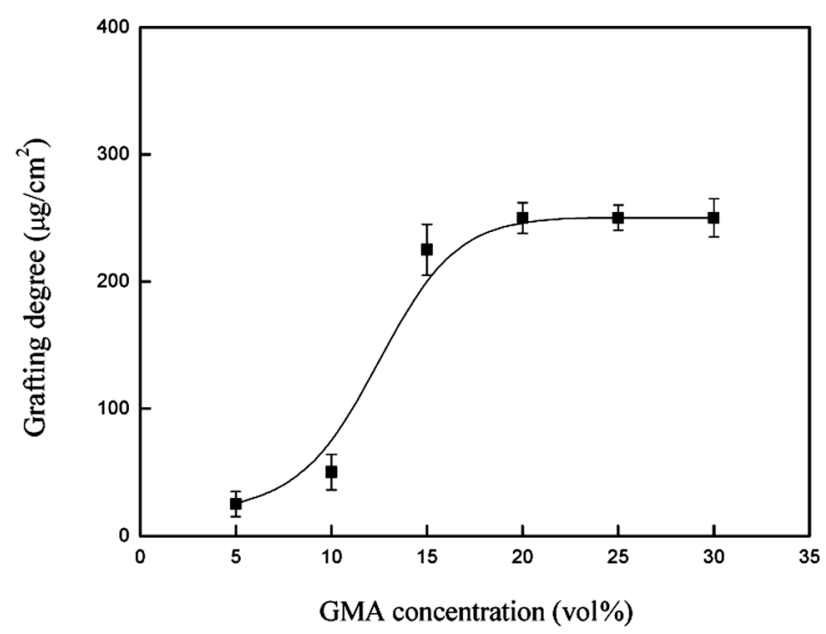

Figure 6. Effect of GMA concentration on the grafting degree of GMA onto PE plate. (Reaction time $4 \mathrm{hr}$, reaction temperature $70^{\circ} \mathrm{C}$ ).

하는 것을 예상할 수 있다. 초기 단량체의 농도가 낮은 용액 에서는 표면의 그래프트 중합반응과 벌크에서의 단일중합체 중합반응이 서로간의 큰 방해 없이 진행이 되어 용액의 농도가 증가할수록 $\mathrm{GD}$ 도 증가하게 된다. 그러나 초기 단 량체의 농도가 어느 정도이상이 되면, 반응이 진행됨에 따라서 벌크 용액의 점도가 증가하여 벌크의 단량체들이 기재의 표면으로 전달되는 속도가 느려지게 될 뿐만 아니라 단량체들이 벌크에서 단일중합체 형성에 빠르게 소모되 어 결국 표면 $\mathrm{GD}$ 가 오히려 줄어드는 현상이 생긴다. 이를 Tromsdorff effect 라고 하며, ${ }^{20,21}$ 보통 용매를 사용하는 그래 프트 용액 중합 반응에서 단량체의 농도가 높을수록 현저 하게 나타난다. 따라서 가장 높은 $\mathrm{GD}$ 를 나타낸 $20 \mathrm{vol} \%$ 를 $\mathrm{GMA}$ 최대 도입 조건으로 선정하였다.

반응 온도에 대한 영향: 본 연구에서는 용매로 쓰인 에 탄올의 끓는점이 $78^{\circ} \mathrm{C}$ 인 점을 감안하여 최대온도를 $80^{\circ} \mathrm{C}$ 로 설정하고 실험을 진행하였다. 처리 시간은 4시간, $\mathrm{GMA}$ 의 농도는 $20 \mathrm{vol} \%$ 로 고정시키고 반응 온도를 변화시켰을 때 $\mathrm{GD}$ 의 변화 경향을 조사하였다. Figure 7에서 보는 바와 같이 $65^{\circ} \mathrm{C}$ 부터 $80^{\circ} \mathrm{C}$ 까지 서서히 증가하는 것을 볼 수 있었다. 따라서 $80^{\circ} \mathrm{C}$ 를 $\mathrm{GMA}$ 최대 도입 조건으로 선정하였다.

반응 시간의 영향: Figure 8은 그래프트 공중합 시간에 따른 GD의 변화를 보여주고 있다. 그래프트 공중합 온도는 $70{ }^{\circ} \mathrm{C}, \mathrm{GMA}$ 농도는 $20 \mathrm{vol} \%$ 로 고정시키고 반응시간을 $1 \sim 7 \mathrm{hr}$ 범위에서 1시간씩 늘려가면서 실험을 진행하였다. 그래프에서 보는 바와 같이 전반적으로 반응 시간이 증가함 에 따라 $\mathrm{GD}$ 는 점차적으로 증가하고 있는 것을 볼 수 있다. 그러나 4시간 이후로는 $\mathrm{GD}$ 의 변화가 거의 없어서 반응이 종결되었음을 알 수 있었다. 따라서 가장 높은 GD 값을 나타낸 4시간을 $\mathrm{GMA}$ 최대 도입 조건으로 결정하였다.

ATR-FTIR 분석. Figure 9는 PE의 ATR-FTIR 스펙트럼을 보여주고 있다. (a)는 아무것도 처리 하지 않은 PE이고, (b)는

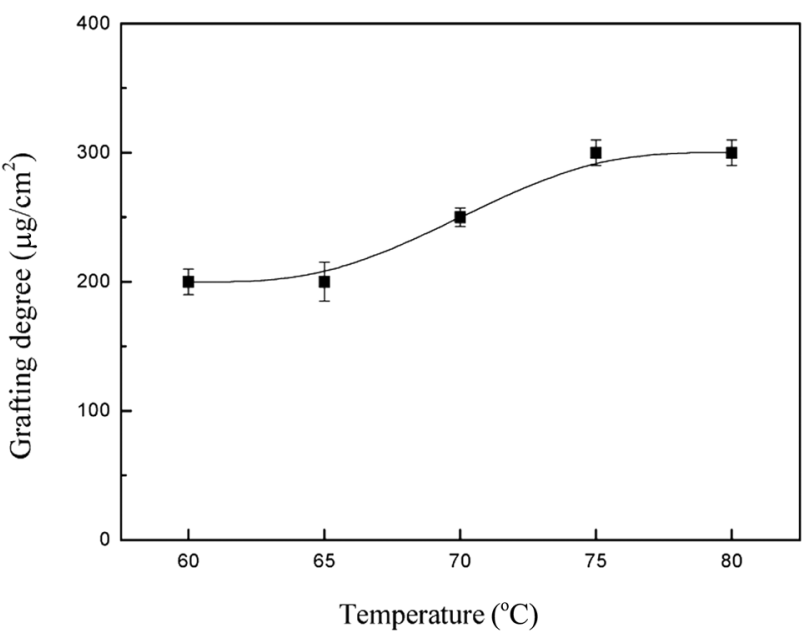

Figure 7. Effect of reaction temperature on the grafting degree of GMA onto PE plate. (Reaction time $4 \mathrm{hr}$, GMA concentration $20 \mathrm{vol} \%)$.

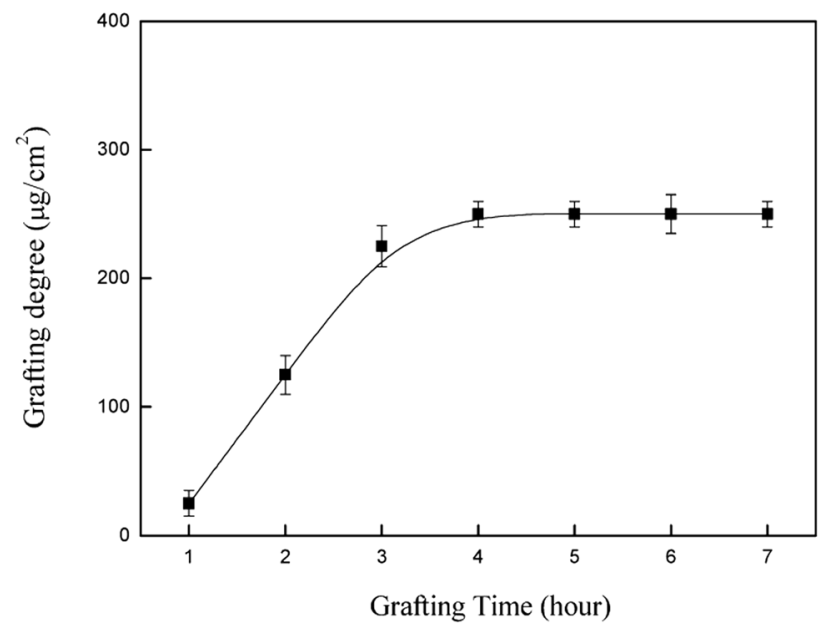

Figure 8. Effect of reaction time on the grafting degree of GMA onto PE plate. (Reaction temperature $70^{\circ} \mathrm{C}$, GMA concentration 20 vol\%).

플라즈마 처리한 $\mathrm{PE}$ 표면에 $\mathrm{GMA}$ 를 그래프트 공중합시킨 PE-g-PGMA(polyGMA) 시료의 스펙트럼이다. (b)는 앞서 실 험을 토대로 하여 얻어낸 $\mathrm{GMA}$ 최대 도입 조건으로 얻어 낸 결과이다. (a)와 (b)의 스펙트럼 중에 $2800-2900 \mathrm{~cm}^{-1}$ 영 역에서 아주 강한 피크를 보이고 있는데 이는 $\mathrm{C}-\mathrm{H}$ 결합 으로, $\mathrm{PE}$ 와 PE-g-PGMA에 존재하는 $\mathrm{CH}_{2}$ 를 확인할 수 있다. 스펙트럼 (a)와는 다르게 (b)의 $1726.59 \mathrm{~cm}^{-1}$ 에서 관찰된 피크 는 분석결과 카보닐기 $(\mathrm{C}=\mathrm{O})$ 이고, $1171.59 \mathrm{~cm}^{-1}$ 에서 나타난 피크는 GMA의 에스테르기(C-O-C)이다.22 또한 스펙트럼 (b) 에서 $800-990 \mathrm{~cm}^{-1}$ 부근의 $850.05,907.85,965.70 \mathrm{~cm}^{-1}$ 의 피 크는 (a)와 비교하였을 때 약간의 변화를 보였고 이 영역에 서 나타난 피크는 고리형 에테르기인 에폭시기이다. 따라 서 이 분석결과를 토대로 본 실험을 통하여 $\mathrm{PE}$ 에 $\mathrm{GMA}$ 


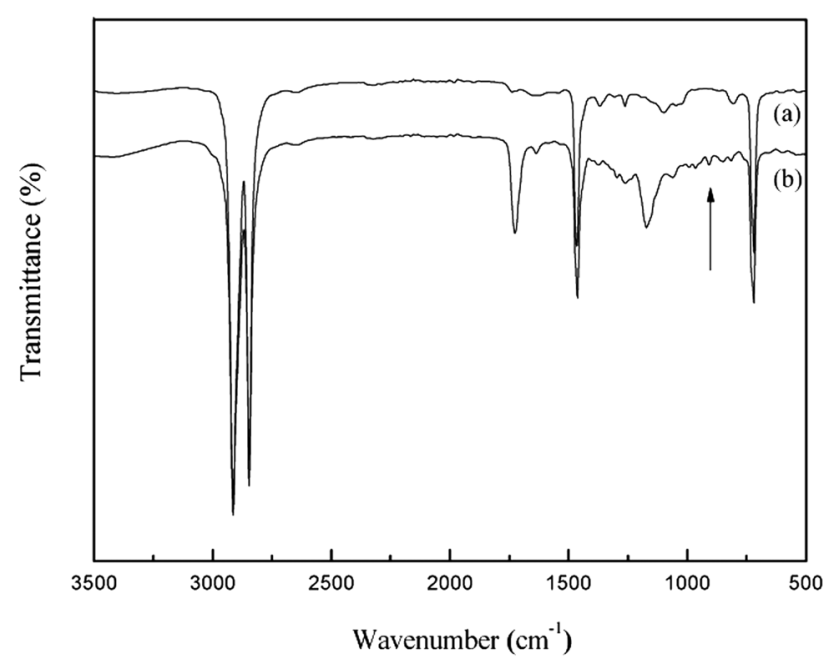

Figure 9. FTIR spectra of (a) pure PE; (b) PE-g-PGMA (PE-g-PGMA conditions: plasma treatment time $600 \mathrm{sec}, \mathrm{RF}-$ power $200 \mathrm{~W}$, Ar gas flow rate $5 \mathrm{LPM}$, sample speed $20 \mathrm{~mm} / \mathrm{sec}$; reaction temperature $80^{\circ} \mathrm{C}$, GMA concentration $20 \mathrm{vol} \%$, reaction time $4 \mathrm{hr}$ ).

\section{가 그래프트되었음을 알 수 있었다.}

XPS 분석. 플라즈마 처리 후 XPS 분석을 통하여 표면 의 원소 구성비와 각 원소의 화학결합상태를 확인하였다. Figure 10에 나타낸 것처럼 분석에 사용된 시편은 아무 처리도 하지 않은 $\mathrm{PE}(\mathrm{a})$ 와 플라즈마 처리된 $\mathrm{PE}(\mathrm{b})$, 플라즈마 처리한 PE 표면에 GMA를 그래프트시킨 PE-g-PGMA(c) 로 나누어 비교하였다. 플라즈마 처리 조건은 RF-power $200 \mathrm{~W}, \mathrm{Ar}$ 유량 $5 \mathrm{LPM}$, 처리시간 $600 \mathrm{sec}$, 시편 홀더의 이 동속도 $20 \mathrm{~mm} / \mathrm{sec}$ 으로 표면 자유에너지가 가장 높게 나온 조건으로 설정하였다. 그래프트 공중합의 조건은 온도 $80^{\circ} \mathrm{C}$, 반응시간 $4 \mathrm{hr}, \mathrm{GMA}$ 농도 $20 \mathrm{vol} \%$ 로 $\mathrm{GD}$ 가 가장 높게 나온 조건으로 설정하였다. Figure 10에서 (a)보다 (b)와 (c)에서 $\mathrm{O} 1 \mathrm{~s}$ 의 피크가 상대적으로 증가했음을 알 수 있다. 이에 대한 정량적 분석자료는 Table 6에 나타내었다. Table 6의 (a), (b), (c)를 비교하여 보면 탄소의 양은 $93.13 \%, 71.07 \%$, $77.07 \%$ 로, 산소의 양은 $6.59 \%, 25.18 \%, 21.94 \%$ 의 순으로 변 화하였다. 플라즈마 처리를 함으로써 $\mathrm{PE}$ 표면에 산소의 양이 $6.59 \%$ 에서 $25.18 \%$ 로 증가하고 탄소는 $91.13 \%$ 에서 $71.07 \%$ 로 줄어들었음을 알 수 있었다.

이를 자세히 분석하기 위하여 (a)와 (b)를 C1s core level에 서 curve fitting을 통하여 피크를 분리하였다. Figure 11에서 보는 바와 같이 (a)에서 잘 나타나지 않았던 하이드로퍼옥 사이드의 피크가 (b)에 나타난 것을 볼 수 있다. 즉, 대기압 플라즈마 처리 후 더 높은 결합에너지에 해당하는 새로운 극성 관능기가 $\mathrm{PE}$ 표면에 형성됨을 알 수 있다. Table 7에서 $\mathrm{C} 1 \mathrm{~s}$ 의 피크 분리를 통해 얻은 각각의 피크 면적으로부터 계산된 시료 (a)와 (b)의 관능기 함량을 분석해보면, (b)는 (a)에 비하여 C-C group의 양은 $93.7 \%$ 에서 $80.39 \%$ 로 줄어든 반면에, C-O group은 $5.41 \%$ 에서 $11.11 \%$ 로 약 두 배 증가하

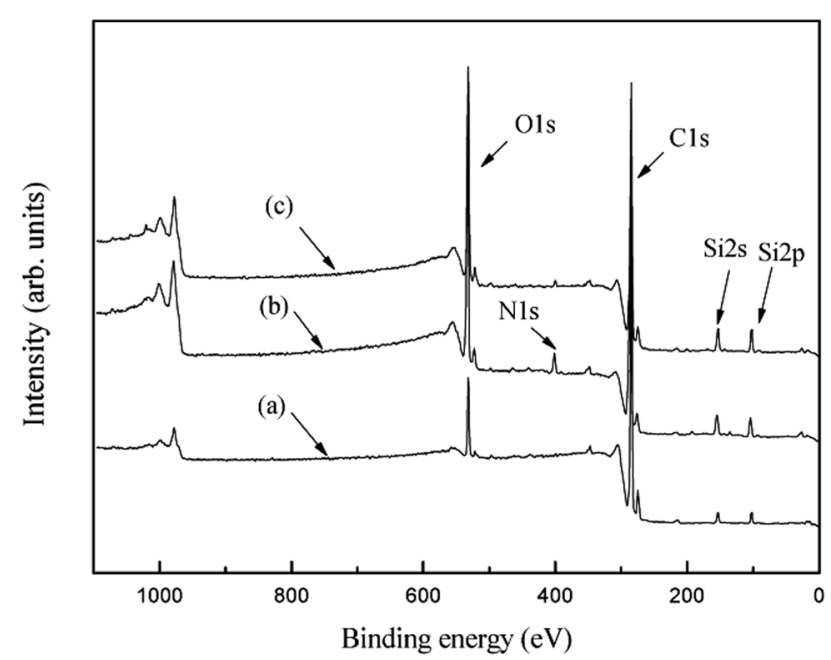

Figure 10. XPS survey scan spectra of (a) pure PE; (b) plasma treated PE; (c) PE-g-PGMA.

Table 6. Atomic Concentration of (a) Pure PE, (b) Plasma Treated PE, and (c) PE-g-PGMA

\begin{tabular}{lccc}
\hline & \multicolumn{3}{c}{ Atomic concentration(\%) } \\
\cline { 2 - 4 } & $\mathrm{C}$ & $\mathrm{N}$ & $\mathrm{O}$ \\
\hline (a) Pure PE & 93.13 & 0.28 & 6.59 \\
(b) Plasma treated PE & 71.07 & 3.75 & 25.18 \\
(c) PE-g-PGMA & 77.07 & 0.99 & 21.94 \\
\hline
\end{tabular}

였고, 하이드로퍼옥사이드의 경우에는 $1.12 \%$ 에서 $8.51 \%$ 로 약 8 배 증가했음을 알 수 있다. 이를 통해 $\mathrm{PE}$ 의 표면이 플라 즈마 처리 시 대기 중에 노출되어 산화되기 때문에 산소의 양이 증가하였다고 사료된다.

Figure 11에서 보는 바와 같이 플라즈마 처리된 $\mathrm{PE}$ (Figure 11(b))에 그래프트 공중합을 통하여 생성된 PE- $g$-PGMA (Figure 11(c))는 (b)와는 달리 (c)에서 하이드로퍼옥사이드 의 피크는 없어지고, $\mathrm{COO}$ group이 나타난 것을 알 수 있다. Table 7에 분석된 관능기 함량을 통하여 PE-g-PGMA에서 $-\mathrm{CO},-\mathrm{COO}$ group이 각각 $17.06 \%, 3.3 \%$ 가 도입되었음을 알 수 있었다.

SEM 분석. Figure 12는 플라즈마 처리 전과 플라즈마 처리 후, 그래프트 공중합 후의 PE 표면을 각각 5000 배와 10000 배로 확대한 SEM 사진이다. 순수한 시료와 플라즈마 처리 후의 시료를 살펴보면 플라즈마 처리 후 시료의 표면이 좀 더 매끄러워진 것을 알 수 있었다. 또한 5000배 확대한 사진의 플라즈마 처리 후와 그래프트 공중합 처리 후의 표면 결과를 비교해 보면 그래프트 공중합 처리 후의 표면에 있 던 에칭이 줄어들고, 아무것도 처리하지 않은 $\mathrm{PE}$ 의 표면 과 유사한 모습을 보인다. Wang은 $2 \mathrm{AFM}$ 분석에 나타난 흰점들을 통하여 $\mathrm{GMA}$ 가 $\mathrm{PE}$ 표면에 그래프트되었다는 것을 

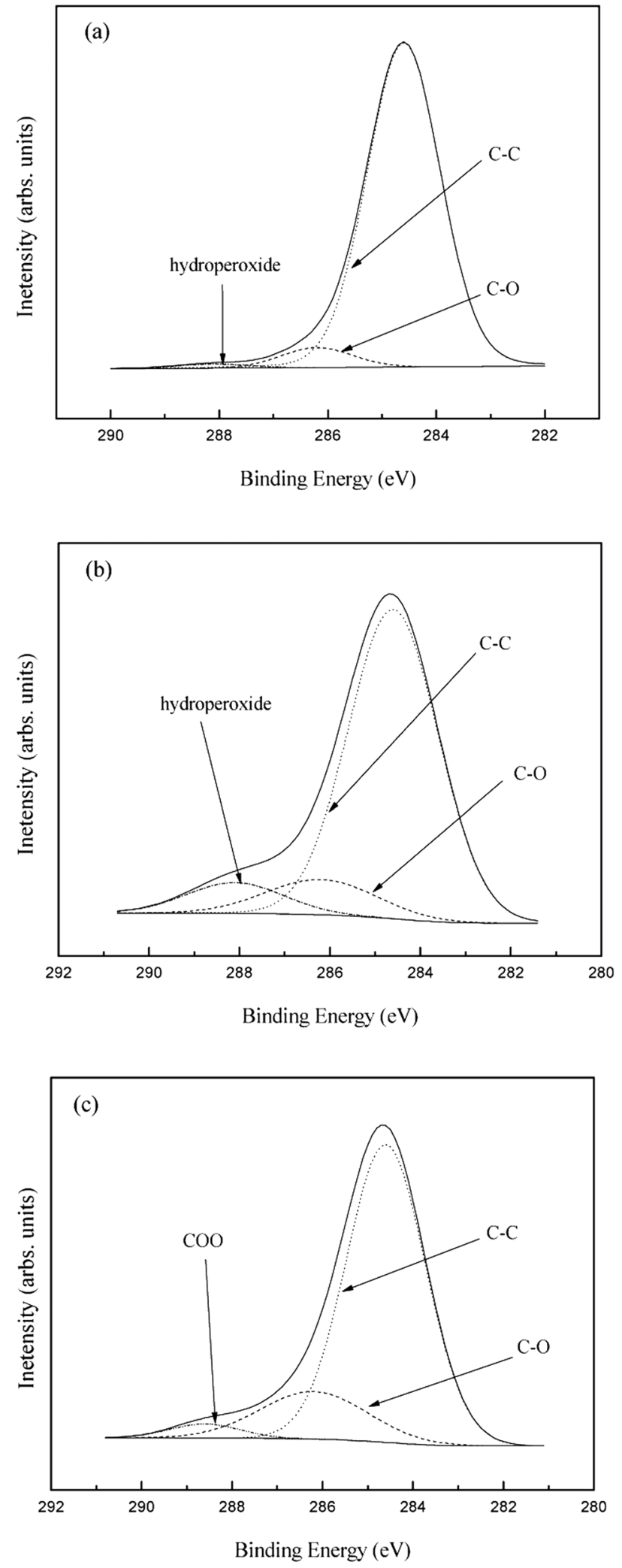

Figure 11. C1s core level spectra of (a) pure PE; (b) Plasma treated PE; (c) PE-g-PGMA.
Table 7. Percentage of Carbon Components on (a) Pure PE, (b) Plasma Treated PE, and (c) PE-g-PGMA

\begin{tabular}{lcccc}
\hline & $\mathrm{C}-\mathrm{C}$ & $\mathrm{C}-\mathrm{O}$ & Hydroperoxide & $\mathrm{COO}$ \\
\cline { 2 - 5 } & $\begin{array}{c}284.6 \\
(\mathrm{eV})\end{array}$ & $\begin{array}{c}286.2 \\
(\mathrm{eV})\end{array}$ & $\begin{array}{c}288.1 \\
(\mathrm{eV})\end{array}$ & $\begin{array}{c}288.6 \\
(\mathrm{eV})\end{array}$ \\
\hline (a) Pure PE & 93.7 & 5.41 & 1.12 & 0 \\
(b) Plasma treated PE & 80.39 & 11.11 & 8.51 & 0 \\
(c) PE-g-PGMA & 79.62 & 17.06 & 0 & 3.32 \\
\hline
\end{tabular}

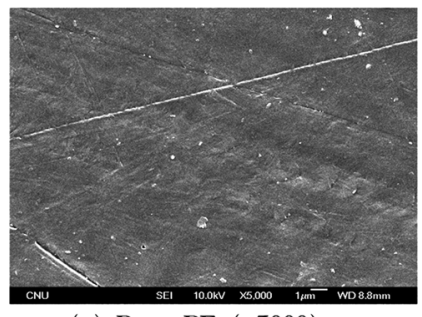

(a) Pure PE (x5000)

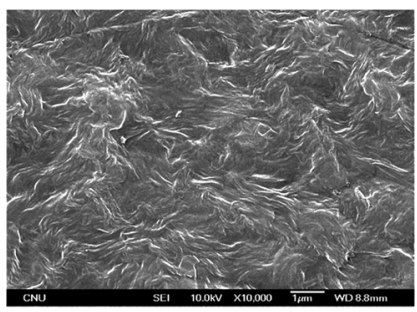

(d) Pure PE (x10000)

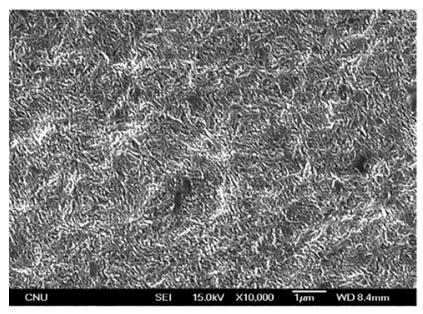

(e) Plasma treated PE (x10000)

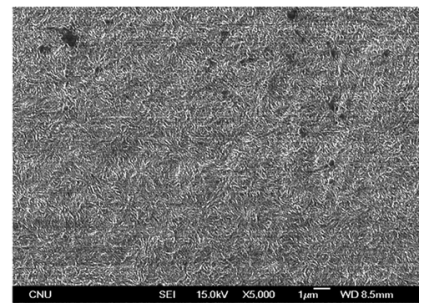

(b) Plasma treated PE (x5000)

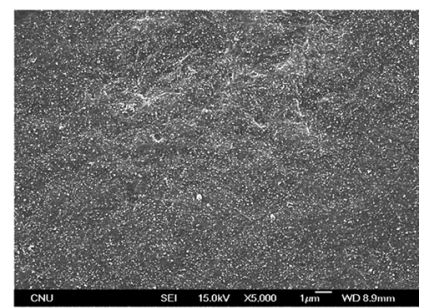

(c) PE-g-PGMA ( $x 5000)$

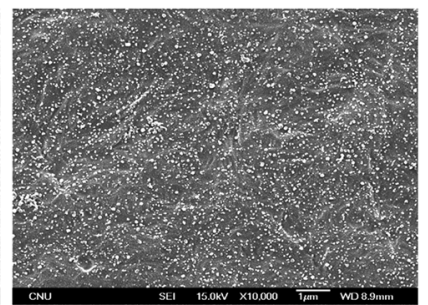

(f) PE-g-PGMA (x10000)
Figure 12. SEM analysis of polyethylene surface.

알아내었다. 이를 토대로 Figure 12의 10000배 확대한 사 진에서는 표면에 보이는 흰점이 GMA가 PE 표면에 그래 프트되었다는 것을 보여준다.

\section{결 론}

본 연구에서 얻어진 결과를 정리하면 다음과 같다.

1) $\mathrm{PE}$ 에 대한 $\mathrm{Ar}$ 가스를 사용한 대기압 플라즈마 장치의 처리 조건은 RF-power $200 \mathrm{~W}$, 플라즈마 처리시간 $600 \mathrm{sec}$, $\mathrm{Ar}$ 가스의 유량 $5 \mathrm{LPM}$, 시편 홀더의 이동속도 $20 \mathrm{~mm} / \mathrm{sec}$ 에서 최적임을 알 수 있었다.

2) $\mathrm{Ar}$ 플라즈마 처리된 $\mathrm{PE}$ 에 $\mathrm{GMA}$ 를 그래프트 공중합 하는 과정에서 반응온도 $80^{\circ} \mathrm{C}$, 반응시간 $4 \mathrm{hr}, \mathrm{GMA}$ 농도 $20 \mathrm{vol} \%$ 일 때 최대의 $\mathrm{GD}$ 를 가진다. 
3) FTIR 분석 결과, $1726.59 \mathrm{~cm}^{-1}$ 에서 카르보닐기가 관찰 되었고, $1171.59 \mathrm{~cm}^{-1}$ 에서 $\mathrm{GMA}$ 의 에스테르기가 관찰되었 으며, $850.05,907.85,965.70 \mathrm{~cm}^{-1}$ 에서 에폭시기를 나타낸 것 으로 보아 성공적으로 그래프트 공중합을 하였으며, 에폭시 기가 PE 표면에 도입되었음을 확인되었다.

4) XPS 분석을 통하여 정량적으로 산소함유관능기의 양을 산출하였다. XPS의 전체 스펙트럼에서 산소의 함량이 표면처리전 $\mathrm{PE}$, 플라즈마 표면처리된 PE, PE- $g$-PGMA에서 $6.59 \%, 25.18 \%, 21.95 \%$ 로 증가하였다가 약간 감소하는 경향을 보이는데, 이는 플라즈마 처리 시 대기 중에서 표면 산화가 이루어진 것이고, 그래프트 공중합 과정에서는 하 이드로퍼옥사이드기를 개시제로 GMA가 도입되면서 그 양이 조금 줄어드는 것이다.

5) XPS C1s core level spectra 분석 결과 PE- $g$-PGMA 에서 기존의 $\mathrm{PE}$ 와 플라즈마 처리된 $\mathrm{PE}$ 에서 나타나지 않았던 $\mathrm{COO}$ group의 함량이 $0 \%$ 에서 $3.32 \%$ 로 증가함으로써 $\mathrm{PE}$ 에 $\mathrm{GMA}$ 가 그래프트된 것이다.

감사의 글: 본 과제(결과물)는 (주)바이오니아의 지원 하에 수행된 BK21 사업 “대덕특구연계에너지환경소재혁 신인력양성사업단" 개발과제의 연구 결과입니다.

\section{참 고 문 헌}

1. S. M. Yun, S. W. Woo, E. Jeong, B. C. Bai, I. J. Park, and Y. S. Lee, Appl. Chem. Eng., 21, 343 (2010).

2. H. Wang and J. Han, J. Colloid Interface Sci., 333, 171 (2009).

3. C. M. Chen, T. E. Hsieh, and M. O. Liu, React. Funct. Polym., 68, 1307 (2008).

4. N. Seko, L. T. Bang, and M. Tamada, Nucl. Inst. Methods Phys. Res. B, 265, 146 (2007).

5. N. Seko and N. T. Y. Ninh, Radiat. Phys. Chem., 79, 22 (2010).
6. K. Yamada and S. Tageda, J. Appl. Polym. Sci., 103, 493 (2007).

7. O. J. Kwon, S. Tang, L. Lu, and H. S. Choi, J. Soc. Adhes. Interface(Korea), 4, 1 (2003).

8. J. S. Jung, I. Y. Yang, S. W. Myung, H. S. Choi, and J. H. Kim, Polymer(Korea), 31, 308 (2007).

9. D. H. Sim and S. D. Seul, Polymer(Korea), 32, 433 (2008).

10. J. H. Park, S. N. Yun, and Y. B. Ham, J. the Korea Fluid Power System Society, 5, 23 (2008).

11. Y. S. Kim, O. J. Kwon, E. H. Kim, S. W. Myung, and H. S. Choi, Hwahak Konghak, 41, 224 (2003).

12. H. S. Choi, Y. S. Kim, Y. Zhang, S. Tang, S. W. Myung, and B. C. Shin, Surf. Coat. Technol., 182, 55 (2004).

13. D. Wang, G. Sun, and B. Xiang, Eur. Polym. J., 44, 2032 (2008).

14. B. Martel, P. L. Thuaut, G. Crini, M. Morcellet, A. M. Naggi, U. Maschke, S. Bertini, C. Becchi, X. Coqueret, and G. Torri, J. Appl. Polym. Sci., 78, 2166 (2000).

15. H. Huang and N. C. Liu, J. Appl. Polym. Sci., 67, 1957 (1998).

16. J. Zhang, K. Kato, Y. Uyama, and Y. Ikada, J. Polym. Sci., 33, 2629 (1995).

17. K. Allmer, A. Hult, and B. Ranby, J. Polym. Sci., 27, 3405 (1989).

18. Q. Zhao, Y. Liu, and E. W. Abel, J. Colloid Interface Sci., 280, 174 (2004).

19. M. H. Jung and H. S. Choi, J. Electrochem. Soc., 155, H334 (2008).

20. L. Jun, L. Jun, Y. Min, and H. Hongfei, Radiat. Phys. Chem., 60, 625 (2001).

21. A. Matsumotoa, D. Mitomi, H. Aota, and J. Iked, Polymer, 41, 1321 (2000).

22. L. Jun, Z. Yuxia, and Z. Yuzhen, Construct. Build. Mater, 22, 1067 (2008). 